\title{
Diagnostic difficulties in a patient with generalized pustular psoriasis
}

\section{Trudności diagnostyczne u pacjenta z uogólnioną łuszczycą krostkową}

Katarzyna Juczyńska

Department of Dermatology and Venereology, Medical University of Lodz, Lodz, Poland

Przegl Dermatol 2014, I0I, 477-480

DOI: 10.5 | |4/dr.2014.46949

\section{KEY WORDS:}

pustular psoriasis, acute generalized exanthematous pustulosis.

SŁOWA KLUCZOWE:

łuszczyca krostkowa, ostra uogólniona osutka krostkowa.
ADDRESS FOR CORRESPONDENCE:

Katarzyna Juczyńska MD

Department of Dermatology

and Venereology

Medical University of Lodz

1 Hallera Sq. build. 6

90-647 Lodz, Poland

tel.: +48426393093

e-mail: juczynska@yahoo.com

\begin{abstract}
Introduction. Generalized pustular psoriasis is an uncommon, severe form of psoriasis. It may have a chronic, recurrent clinical course after rapid onset.

Objective. To present diagnostic problems in a patient with a medical history of rheumatoid arthritis and sudden onset of generalized pustular eruption.

Case report. A 66-year-old patient with rheumatoid arthritis, treated with immunosuppressants, was admitted to our department with acute, generalized pustular eruption. Histopathological findings in skin biopsy were equivocal; however, clinical diagnosis of pustular psoriasis was established. The diagnosis was sustained in longer perspective as slow regression of pustular eruptions and chronic, recurrent nature of skin lesions were observed.

Conclusions. The presented case report along with data from the literature indicate that clinical and histopathological diagnosis of pustular psoriasis can be difficult. It is suggested that immunosuppressive therapy can affect both histopathological findings and therapy outcome.
\end{abstract}

\section{STRESZCZENIE}

Wprowadzenie. Uogólniona łuszczyca krostkowa jest rzadką, ciężką postacią łuszczycy. Po nagłym początku może mieć przewlekły, nawrotowy przebieg.

Cel pracy. Przedstawienie problemów diagnostycznych u pacjenta $\mathrm{z}$ reumatoidalnym zapaleniem stawów i nagłym wysiewem uogólnionych zmian krostkowych.

Opis przypadku. Pacjent 66-letni z reumatoidalnym zapaleniem stawów, leczony lekami immunosupresyjnymi, został przyjęty do Kliniki z nagłym uogólnionym wysiewem zmian krostkowych. Choć wynik badania histopatologicznego był niejednoznaczny, ustalono rozpoznanie łuszczycy krostkowej. Powolne ustępowanie zmian skórnych i ich przewlekły, nawracający charakter podtrzymały postawioną diagnozę. Wnioski. Przedstawiony przypadek oraz dane z piśmiennictwa wskazują, że kliniczna i histopatologiczna diagnoza łuszczycy krostkowej może nastręczać trudności. Sugeruje się, że leczenie immunosupresyjne może wpływać zarówno na wynik badania histopatologicznego, jak i efekty leczenia. 


\section{INTRODUCTION}

Generalized pustular psoriasis (GPP) characterized by sterile pustules is an uncommon, severe form of psoriasis and is considered as a potentially life-threatening disease. Its onset may be subacute, acute or fulminant, followed by recurrent course [1]. Pustular eruption may be the only manifestation of the disease, but it may also occur in patients with a previous or future history of psoriasis vulgaris [2]. Factors such as infections, pregnancy, drugs $[3,4]$ and their sudden withdrawal [5, 6] are considered as possible triggers of skin lesions. The flares of pustules are accompanied by fever, leucocytosis and liver abnormalities [7, 8].

Diagnosis of GPP is based on the characteristic course of the disease, its clinical features and histopathological findings. When presenting rapid onset and systemic symptoms, generalized pustular psoriasis should be differentiated from acute generalized exanthematous pustulosis (AGEP) because in both diseases suddenly appearing pustular eruption on an erythematous base, often accompanied by fever, is observed.

AGEP is induced in $90 \%$ of cases by drugs, and occasionally by viral infections [9] or insect bites [10, 11]. Rapid and non-recurrent course of the disease with spontaneous healing within 15 days after elimination of the provoking factor is characteristic for this disease [9, 12]. In AGEP blood eosinophilia is present in approximately $30 \%$ of patients [12], while in pustular psoriasis leucocytosis and liver abnor-

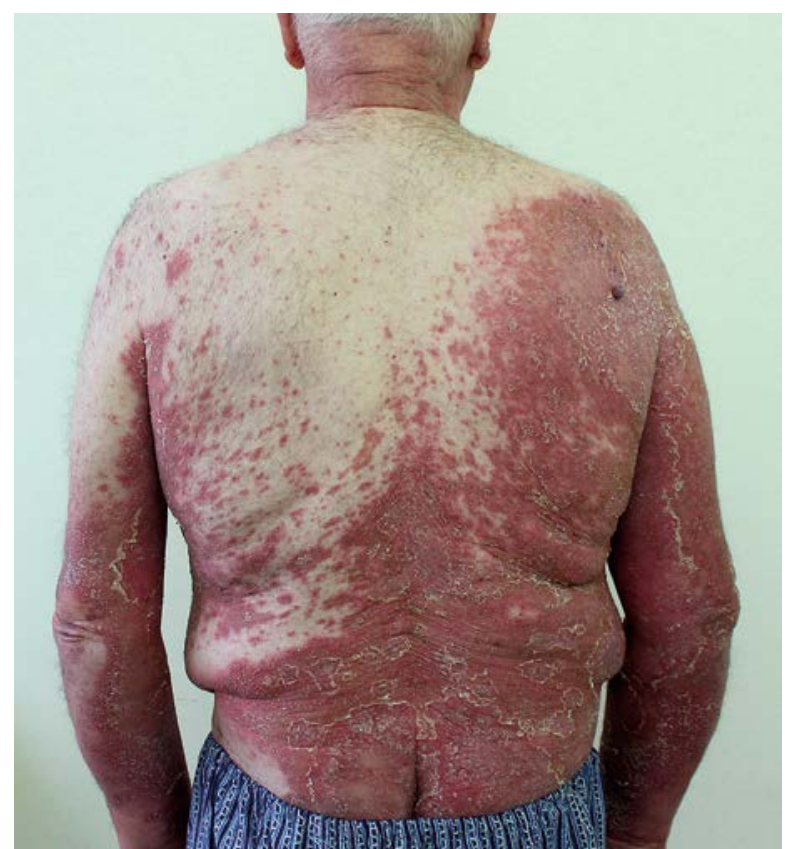

Figure I. Generalized erythema with desquamation and multiple pustules

Rycina I. Uogólniony rumień ze złuszczaniem i licznymi krostkami malities may be found. Personal history of psoriasis is of no importance in differentiation, as AGEP may occur in patients with a history of this disease.

Histopathological differentiation between general pustular psoriasis and AGEP may also be a challenge, because of existing overlaps and subtle histopathological differences between them. It is even suggested that distinguishing between these two diseases relying only on histopathological findings is impossible [12]. Histopathological features more often seen in pustular psoriasis are superficial, and spongiform pustules without eosinophils and with more lysed keratinocytes are observed. Psoriasiform changes in the epidermis, such as hyperkeratosis, acanthosis, and rete ridge changes, may not be prominent until the chronic stage $[12,13]$. In AGEP pustules with eosinophils in the dermis and necrotic keratinocytes as well as deeper, interstitial and mid-dermal infiltration consisting of neutrophils and eosinophils are present.

To enhance AGEP diagnosis and to evaluate its probability Sidoroff et al. proposed the scoring system based on case-control studies, including course of the disease as well as morphological and histopathological criteria [14]. However, this system has limitations, as pustular eruptions lasting more than 3 weeks were not taken into consideration and there have been no controlled studies validating the scale.

The first line treatment of pustular psoriasis includes systemic therapy with immunosuppressants. Satisfactory clinical outcomes were reported after use of methotrexate, cyclosporin A, and acitretin [15-17].

\section{OBJECTIVE}

The objective of this report is to present diagnostic problems in a patient with a medical history of rheumatoid arthritis and arterial hypertension, treated with immunosuppressive agents, who suddenly developed generalized pustular eruption on an erythematous base accompanied by systemic symptoms.

\section{CASE REPORT}

A 66-year-old man with a medical history of rheumatoid arthritis and arterial hypertension was admitted to the Department of Dermatology and Venerology, Medical University of Lodz, in November 2013 with generalized erythematous, desquamative and pustular eruption accompanied by fever up to $38^{\circ} \mathrm{C}$, shivers and fatigue (Figures $1-3$ ).

The lesions developed abruptly, 3 weeks before admission, and were initially localized on both forearms and shins then rapidly developed on arms, 


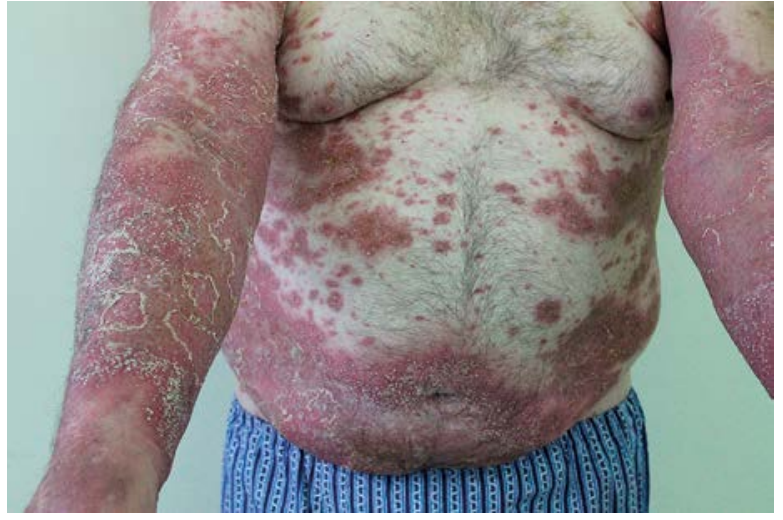

Figure 2. Erythemas and plaques with desquamation. Pustules on plaques

Rycina 2. Rumienie ze złuszczaniem i ogniska zmian krostkowych

trunk, buttocks and legs. There was no history of antecedent infection, insect bite, new drug used or any drug withdrawal. At admission the patient was taking azathioprine $(75 \mathrm{mg} /$ day $)$ and methylprednisolone $(6 \mathrm{mg}$ /day) as a therapy for rheumatoid arthritis diagnosed over 20 years before, along with amlodipine $(5 \mathrm{mg}$ /day) for arterial hypertension. Those therapeutic agents and their dosage remained unchanged for the last 3 years.

In the Department of Dermatology medical examinations were performed. The pustular eruption was associated with typical psoriatic changes found on nails and scalp. Family history of psoriasis was negative. Laboratory results revealed normocytic anemia. Liver and renal function tests, glucose level and urine analysis were normal.

Histopathological examination of skin biopsy revealed epidermis without any pathologic changes and in the dermis perivascular infiltrations composed mainly of lymphocytes and eosinophils and only focally of neutrophils. This picture was classified as equivocal, and no histopathologic changes characteristic for psoriasis were found. Despite this histopathological result, the diagnosis of generalized pustular psoriasis was established based on medical history, clinical features of skin lesions, course of the disease and lack of any known AGEP provoking factor.

The patient was initially treated with higher (than initial) doses of methylprednisolone $(16 \mathrm{mg} /$ day $)$ and azathioprine $(100 \mathrm{mg} /$ day). The therapy resulted in a body temperature decrease, but there was no significant clinical improvement of skin lesions. Moreover, new plaques with pustules were noticed. Second-line treatment was cyclosporine A $(300 \mathrm{mg} /$ day) along with azathioprine and methylprednisolone. There was further clinical progression of skin lesions accompanied by fever up to $38^{\circ} \mathrm{C}$. After failure of high-doses immunosuppressive therapy, all drugs were withdrawn (in agreement with rheuma-

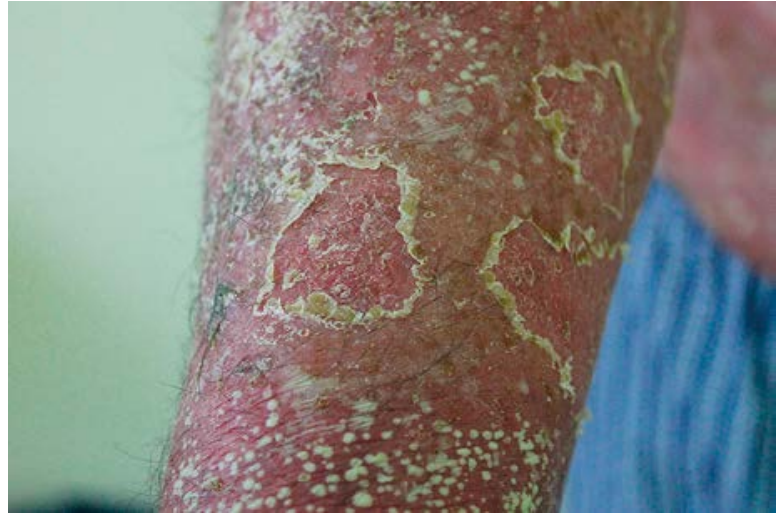

Figure 3. Pustules on erythematous-desquamative surface on upper limb

Rycina 3. Krostki na podłożu zmian rumieniowo-złuszczajq̨cych zlokalizowane na kończynie górnej

tologists) and the patient started to be treated with methotrexate (15 mg/pulse/week). Significant but slow clinical improvement was noted, no new pustules or erythemas developed, and the existing ones started to diminish. In order to sustain clinical remission, the patient has continued therapy with methotrexate (for 10 months), initially in the $15 \mathrm{mg} /$ pulse/ week regimen, and after 5 months the dose was reduced to $10 \mathrm{mg} /$ pulse week. During the treatment, occasionally single new psoriatic plaques and erythemas with pustules were observed.

\section{DISCUSSION}

In the presented case, differentiation between pustular psoriasis and AGEP was difficult, due to equivocal histopathological findings in skin biopsy, rapid onset of the disease, accompanying systemic symptoms and clinical features that may be shared by both diseases. It was not possible to use Sidoroff's validating system for AGEP because skin lesions at admission lasted for 3 weeks.

In our case lack of any known provocative factor (recently started or withdrawn drugs, infection, insect bite), positive response to methotrexate and slow regression of lesions supported the clinical diagnosis of pustular psoriasis in the absence of typical histopathological findings. The diagnosis was confirmed by chronic and recurrent course of the disease, as after rapid onset of the disease new psoriatic plaques and erythemas with pustules were observed.

As reported in the literature, histopathology findings in the acute stage of general pustular psoriasis may significantly differ from those of the chronic stage, and characteristic psoriasiform changes in the epidermis may not be revealed until the chronic stage of the disease [12]. In our case, a skin biopsy was taken in an early phase, which could have considerably affected the dermatopathology results. 
Moreover, the histopathological findings could have been affected by the long-term immunosuppressive treatment the patient was administered. The inhibitory effect of methylprednisolone and azathioprine on antigen-presenting cells and T lymphocytes could have an impact on immunologic cellular mechanisms of psoriasis and contribute to non-characteristic histopathological findings.

\section{References}

1. Augey F., Renaudier P., Nicolas JF.: Generalized pustular psoriasis (Zumbusch): a French epidemiological survey. Eur J Dermatol 2006, 16, 669-673.

2. Naddi L., Gambini D.: The clinical spectrum of psoriasis. Clin Dermatol 2007, 25, 510-518.

3. Brenner M., Molin S., Ruebsam K., Weisenseel P., Ruzicka T., Prinz JC.: Generalized pustular psoriasis induced by systemic glucocorticosteroids: four cases and recommendations for treatment. Br J Dermatol 2009, 161, 964-966.

4. Thakor P., Padmanabhan M., Johnson A., Parajasingam T., Thakor S., Jorgensen W.: Ramipril-induced generalized pustular psoriasis case report and literature review. Am J Ther 2010, 17, 92-95.

5. Griffiths C.E., Barker J.N.: Pathogenesis and clinical features of psoriasis. Lancet 2007, 370, 263-271.

6. Telfer N.R., Dawber R.P.: Generalized pustular psoriasis associated with withdrawal of topical clobetasol-17-proprionate. J Am Dermatol 1987, 17, 144-145.

7. Borges-Costa J., Silva R., Goncalves L., Flipe P., Almeida L.S., Gomes M.M.: Clinical and laboratory features in acute generalized pustular psoriasis a retrospective study of 34 patients. Am J Clin Dermatol 2011, 12, 271-276.

Received: 10 VII 2014

Accepted: $14 \times 2014$
8. Zelicson B.D., Muller S.A. Generalized pustular psoriasis: a review of 36 cases. Arch Dermatol 1991, 127, 1339-1345.

9. Sidoroff A., Duant A., Viboud C., Halevy S., Bavinck J.N., Naldi L., et al.: Risk factors for acute generalized exanthematous pustulosis (AGEP) results of a multinational case-control study (EuroSCAR). Br J Dermatol 2007, 157, 989-996.

10. Davidovici B.B., Pavel D., Cagnano E., Rozenman D., Halevy S.: Acute generalized exanthematosus pustulosis following a spider bite: report of 3 cases. J Am Acad Dermatol 2006, 55, 525-529.

11. Makris M., Spanoudaki N., Giannoula F., Chliva C., Antaniadou A., Kalogeromitros D.: Acute generalized exanthematous pustulosis (AGEP) triggered by a spider bite. Allergol Int 2009, 58, 301-303.

12. Kardaun S.H., Kuiper H., Fidler V., Jonkman M.F.: The histopathological spectrum of acute generalized exanthematosus pustulosis (AGEP) and its differentiation from generalized pustular psoriasis. J Cutan Pathol 2010, 37, 1220-1229.

13. Cribier B.J.: Psoriasis under microscope. JEADV 2006, 20, 3-9.

14. Sidoroff A., Halevy S., Bavinck J.N., Vaillant L., Roujeau J.C.: Acute generalized exanthematous pustulosis (AGEP) - a clinical reaction pattern. J Cutan Pathol 2001, 28, 113-119.

15. Menter A., Chair M.D., Gottlieb A., Feldman S.R., Van Voorhees A., Leonardi C.L., et al.: Guidelines of care for the management of psoriasis and psoriatic arthritis. J Am Acad Dermatol 2008, 58, 826-850.

16. Hazarika D.: Generalized pustular psoriasis of pregnancy successfully treated with cyclosporine. Indian J Dermatol Venereol Leprol 2009, 75, 638-638.

17. Ozawa A., Ohkido M., Haruki Y., Kobayashi H., Ohkawara A., Ohno Y.: Treatment of generalized pustular psoriasis: a mulicenter study in Japan. J Dermatol 1999, 26, 141-149. 